\title{
CONVERGENCE THEOREMS FOR $k$-DIMEICONTACTIVE MAPPINGS IN HILBERT SPACES
}

\author{
Chirasak Mongkolkeha, Yeol Je Cho and Poom Kumam
}

Abstract. In this paper, we prove weak and strong convergence theorems for Moudafi's iterative scheme of two $k$-demicontractive mappings in Hilbert spaces. Our results improve and extend the recent results of Kim and some others.

Mathematics subject classification (2010): 49J40, 47J20.

Keywords and phrases: Hilbert spaces, $k$-dimeicontactive mapping, quasi-nonexpansive mapping, nonexpansive mappings, nonspreading mappings, fixed point problem.

\section{REFERENCES}

[1] R. P. Agarwal, D. O'Regan, D. R. Sahu, Fixed Points Theory for Lipschitzain-type Mappings with Applications, Springer-Verlag (2008).

[2] F. E. BROWDER, Convergence theorems for sequences of nonlinear operators in Banach spaces, Math. Z., 100 (1967), 201-225.

[3] F. E. BRowder, Semicontractive and semiaccretive nonlinear mappings in Banach spaces, Bull. Amer. Math. Soc., 74 (1968), 660-665.

[4] K. Goebel, W. A. Kirk, Topics in Metric Fixed Point Theory, Cambridge University Press, Cambridge (1990).

[5] K. Goebel, S. ReIch, Uniform Convexity, Hyperbolic Geometry, and Nonexpansive Mappings, Marcel Dekker Inc., New York (1984).

[6] T. L. Hicks, J. D. KubiceK, On the Mann iteration process in a Hilbert spaces, J. Math. Anal. Appl., 59(1977), 498-504.

[7] S. IEmoto, W. TAKAhashi, Approximating common fixed points of nonexpansive mappings and nonspreading mappings in a Hilbert spaces, Nonlinear Anal., 71 (2009), 2082-2089.

[8] S. H. KHAN, H. F. FUKHAR-UD-DIN, Weak and strong convergence of a scheme with errors for two nonexpansive mappings, Nonlinear Anal., 71 (2005), 1295-1301.

[9] G. E. KIM, Weak and strong convergence theorems of quasi-nonexpansive mappings in a Hilbert spaces, J. Optim. Theory Appl., 152 (2012), 727-738.

[10] F. KOHSAKA, W. TAKAHASHI, Fixed point theorems for a class of nonlinear mappings related to maximal monotone operators in Banach spaces, Arch. Math. (Basel), 91 (2008), 166-177.

[11] F. KOHSAKA, W. TAKAHASHI, Existence and approximation of fixed points of firmly nonexpansivetype mappings in Banach spaces, SIAM J. Optim., 19 (2008), 824-835.

[12] F. KOHSAKA, W. TAKAHASHI, Fixed point theorems for a class of nonlinear mappings relate to maximal monotone operators in Banach spaces, Arch. Math. (Basel), 91 (2008), 166-177.

[13] S. MATSUSHITA, W. TAKAHASHI, Weak and strong convergence theorems for relatively nonexpansive mappings in Banach spaces, Fixed Point Theory Appl., 2004 (2004), 37-47.

[14] A. MoudAFI, Krasnoselski-Mann iteration for hierarchical fixed-point problems, Inverse Problems, 23 (2007), 1635-1640.

[15] Z. OPIAL, Weak convergence of the sequence of successive approximations for nonexpansive mapping, Bull. Amer. Math. Soc., 73 (1967), 591-597.

[16] M. O. Osilike, F. O. Isiogugu, Weak and strong convergence theorems for nonspreading-type mappings in Hilbert spaces, Nonlinear Anal., 74 (2011), 1814-1822. 
[17] S. ReICh, D. Shoikhet, Nonlinear Semigroups, Fixed Points, and Geometry of Domains in Banach Spaces, Imperial College Press, London (2005).

[18] H. F. Senter, W. G. Dotson, JR., Approximating fixedpoints of nonexpansivemappings, Proc. Amer. Math. Sac., 44 (1974), 375-380.

[19] W. TAKAHASHI, Introduction to Nonlinear and Convex Analysis, Yokohama Publishers, Yokohama (2005) (in Japanese)

[20] W. TAKAhASHI, T. TAMURA, Convergence theorems for a pair of nonexpansive mappings, J. Convex Anal., 5 (1998), 45-56.

[21] W. TAKAHASHI, Introduction to Nonlinear and Convex Analysis, Yokohoma Publishers, Yokohoma, 2009.

[22] K. K. TAN, H. K. XU, Approximating fixed points of nonexpansive mappings by the Ishikawa iteration process, J. Math. Anal. Appl., 178 (1993), 301-308. 